\title{
Application of an Ionic Liquid in the Microwave Assisted Extraction of Cytotoxic Metabolites from Fruits of Schinus terebinthifolius Raddi (Anacardiaceae)
}

\author{
Thiago R. Morais, ${ }^{a}$ Ana Paula R. Coutinho, ${ }^{a}$ Fernanda F. Camilo, ${ }^{a}$ Tereza S. Martins, ${ }^{a}$ \\ Patricia Sartorelli, ${ }^{a}$ Mariana H. Massaoka, ${ }^{b}$ Carlos R. Figueiredo ${ }^{b}$ and \\ João Henrique G. Lago*,a \\ ${ }^{a}$ Instituto de Ciências Ambientais, Químicas e Farmacêuticas, Universidade Federal de São Paulo \\ (UNIFESP), 09972-270 Diadema-SP, Brazil \\ ${ }^{b}$ Departamento de Micro, Imuno e Parasitologia, Universidade Federal de São Paulo (UNIFESP), \\ 04023-062 São Paulo-SP, Brazil
}

\begin{abstract}
This work reports the application of an ionic liquid (1-butyl-3-methylimidazolium bromide, $\mathrm{BMImBr}$ ) in the microwave assisted extraction (MAE) of metabolites from fruits of Schinus terebinthifolius. Dried fruits were individually extracted using BMImBr: $\mathrm{H}_{2} \mathrm{O}$ 1:1, v/v (experiment 1) and pure $\mathrm{H}_{2} \mathrm{O}$ (experiment 2 ) by MAE $\left(10 \mathrm{~min}\right.$ at $60{ }^{\circ} \mathrm{C}$ ). After partition using EtOAc, the yield to experiment 1 was about $23 \%$ while to experiment 2 was $0.1 \%$. The EtOAc fraction obtained from experiment 1 was purified by chromatographic methods to afford 3-oxotirucalla-7,24Z-dien27-oic acid, 3 $\alpha$-hydroxytirucalla-7,24Z-dien-27-oic acid, 3 $\alpha$-acetoxytirucalla-7,24Z-dien-27-oic acid, gallic acid, and ethyl gallate, being the first occurrence of the third compound as natural product. Cytotoxic activity was evaluated in vitro against cancer cell lines (A2058, HeLa, SiHa, HCT, SKBR-3, U87, and B16F2Nex2), being 3 $\alpha$-acetoxytirucalla-7,24Z-dien-27-oic acid the more active metabolite with $\mathrm{IC}_{50}$ ranging from $10.9 \pm 1.3$ to $17.3 \pm 1.4 \mu \mathrm{g} \mathrm{mL} \mathrm{mL}^{-1}$, lower than that determined to positive control cisplatin.
\end{abstract}

Keywords: Schinus terebinthifolius, tirucallane triterpenoids, gallic acid derivatives, ionic liquid, MAE, cytotoxic activity

\section{Introduction}

Schinus terebinthifolius Raddi (Anacardiaceae), popularly known as "aroeira-pimenteira", is geographically distributed throughout Brazil, ${ }^{1,2}$ where it has been used by native communities to treat several diseases. ${ }^{3}$ The scientific investigations have highlighted the importance of S. terebinthifolius extracts due to their antiulcer, anti-inflammatory, antiseptic, and antitumor properties. ${ }^{4}$ Chemically, S. terebinthifolius extracts are rich in triterpenoids, ${ }^{5-8}$ especially tirucallane derivatives (masticadienoic acid and schinol) with anti-inflammatory, ${ }^{4}$ antifungal $^{9}$ and antiparasitic ${ }^{10}$ activities. Beside these compounds, phenolic derivatives such as gallic acid, methyl and ethyl gallates as well as flavonoids trans-catechin, miricetrin, miricetin, quercitrin, and afzelin, which displayed antiradical ${ }^{11}$ and cytotoxic ${ }^{12}$ activities, were also isolated.

\footnotetext{
*e-mail: joao.lago@unifesp.br
}

As reported in previous papers, ${ }^{4-12}$ the extraction procedures of bioactive compounds involve the use of toxic organic solvents such as $\mathrm{MeOH}$, acetone, $\mathrm{CHCl}_{3}$ and hexane in large quantities, leading to a significant environmental impact. The growing interest in adopting more environmentally compatible technologies make these processes inadequate. In this aspect, ionic liquids can be considered potential substitutes for organic solvents used in these extractions due to their interesting properties, such as negligible vapor pressure and non-flammability, high solubilization capacity, high chemical and thermal stabilities, possibility of reuse and reduced toxicity. ${ }^{13-16}$ Moreover, ionic liquids have modular properties, since there are numerous possible combinations of cations, anions and substituents, which originate salts with different densities, viscosities, polarities and hydrophilicities. ${ }^{16}$

Recently, the use of ionic liquids in the natural products chemistry has gained importance. ${ }^{17}$ Among the various applications, the use of ionic liquids as extracting agents of compounds with different polarities from aqueous 
extracts such as organic acids, amino acids, phenols and alkaloids emerged as an alternative process of the high efficiency. ${ }^{17}$ Additionally, ionic liquids in combination with more efficient extraction processes, such as microwave or ultrasound, have been successfully employed to extract various types of natural products including alkaloids, phenolic derivatives, terpenes and other metabolites. ${ }^{18-29}$ Due to the high viscosity of the ionic liquids, usually they are used dissolved in water, which lowers the cost of the process. Finally, it is noteworthy that ionic liquids are compounds that absorb microwave very efficiently, making them excellent solvents when this technology is required. ${ }^{18,30}$ Microwave heating is a very efficient process due to the microwaves couple directly with the molecules that are present in the reaction/extraction mixture, leading to a more efficient procedure. The two fundamental mechanisms for transferring energy from microwaves to the substance are dipole rotation and ionic conduction. Due to the ionic character, ionic liquids absorb microwave irradiation extremely well and transfer energy quickly by ionic conduction. ${ }^{31}$ It is worth to mention that the use of microwave is considered a leading technology and sustainable, as it decreases the extraction time, minimizes energy expenditure, increases process efficiency and hence promotes cost reduction of the final product.

In order to minimize the problems associated to the use of conventional methods in the extraction of bioactive compounds of interesting plant species, this work has two main objectives: report the application of an ionic liquid (1-butyl-3-methylimidazolium bromide, BMImBr) in the microwave-assisted extraction process of metabolites from fruits of $S$. terebinthifolius and evaluate the cytotoxic potential of obtained EtOAc fraction, as well as purified metabolites, against several tumor cell lines.

\section{Experimental}

\section{General experimental procedures}

Microwave assisted extraction (MAE) experiments were performed with a MAS-I microwave oven $(2450 \mathrm{MHz}$, Sineo Microwave Chemistry Technology Company) with a maximum delivered power of $1000 \mathrm{~W}$. The temperature was monitored by an infrared probe inside the microwave oven. Sephadex LH-20 (Sigma-Aldrich) was used for the column chromatographic separation, while silica gel $60 \mathrm{PF}_{254}$ (Merck) and silica gel $60 \mathrm{RP}-18 \mathrm{~F}_{254}$ (Merck) were used for analytical and preparative thin-layer chromatography (TLC), respectively. High performance liquid chromatography (HPLC) analysis were performed in a Dionex Ultimate 3000 chromatograph, using a Luna
Phenomenex RP-18 column $(3 \mu \mathrm{m}, 150 \times 5 \mathrm{~mm})$ and an UV-diode array detector (DAD). ${ }^{1} \mathrm{H}$ and ${ }^{13} \mathrm{C}$ nuclear magnetic resonance (NMR) spectra were recorded at 300 and $75 \mathrm{MHz}$, respectively, in a Bruker Ultrashield 300 Avance III spectrometer using $\mathrm{CDCl}_{3}$ (Tedia Brazil) or $\mathrm{CD}_{3} \mathrm{OD}$ (Aldrich) as solvents.

\section{Plant material}

Fruits of S. terebinthifolius were randomly collected from an individual tree at Mogi-Guaçu region (São Paulo State, Brazil) on February 2010 by Dr. Maria Claudia Marx Young from Instituto de Botânica (São Paulo, Brazil), where a reference specimen (SP272591) was deposited.

Preparation of $\mathrm{BMImBr}$ and the extraction using this ionic liquid

1-Butyl-3-methylimidazolium bromide (BMImBr) was prepared as previously described in the literature, with minor modifications. ${ }^{32}$ Succinctly, the molar ratio was 1:1.2 of 1-methylimidazole (99\%, Aldrich) and the 1-bromobutane (99.9\%, Aldrich), respectively. Residual 1-bromobutane was removed by distillation under reduced pressure. Before extraction, the fruits of S. terebinthifolius were dried at $40{ }^{\circ} \mathrm{C}$ during $48 \mathrm{~h}$. After grinding, the extractions were conducted in triplicate. To each procedure, the plant material (approximately $2.0 \mathrm{~g}$ ) was extracted by microwave-assisted extraction (MAE, Figure 1) with $20 \mathrm{~mL}$ of mixture containing $\mathrm{H}_{2} \mathrm{O}$ and $\mathrm{BMImBr} 1: 1$ (v/v)

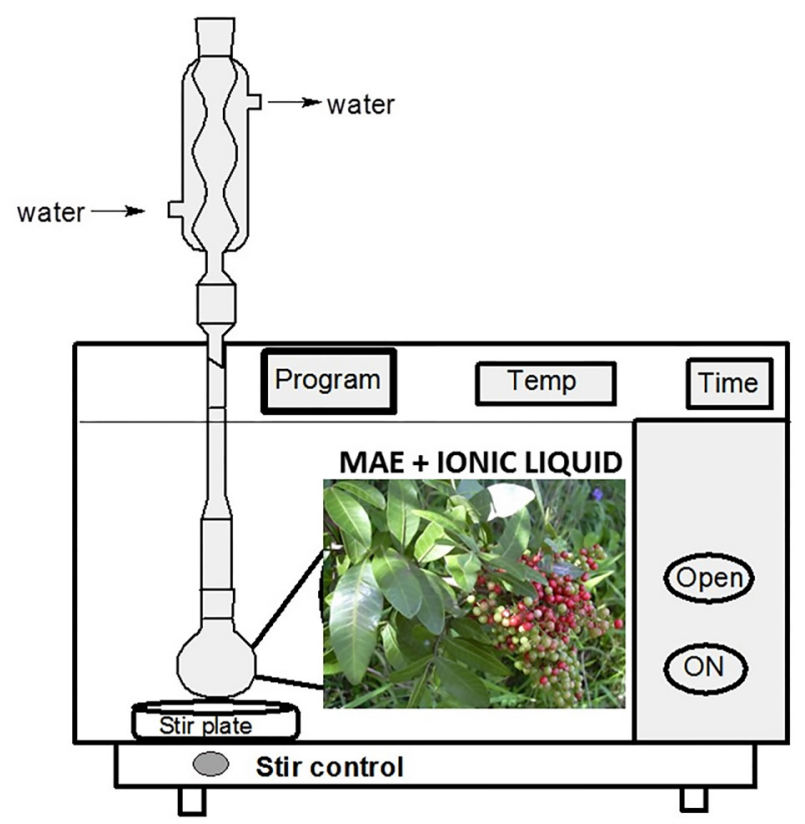

Figure 1. MAE apparatus used for the extraction of fruits of S. terebinthifolius. 
(experiment 1). Additionally, the same procedure was conducted using distillated $\mathrm{H}_{2} \mathrm{O}$ as solvent (experiment 2). To all MAE experiments, the extraction time was $10 \mathrm{~min}$ and extraction temperature was $60{ }^{\circ} \mathrm{C}$.

The obtained aqueous extracts were filtered and then diluted to $5 \mathrm{~mL}$ with deionized $\mathrm{H}_{2} \mathrm{O}$. Sequentially, each aqueous solution was extracted using EtOAc $(3 \times 25 \mathrm{~mL})$. After dried over $\mathrm{Na}_{2} \mathrm{SO}_{4}$ and distillation of the solvent under reduced pressure, were obtained $460 \pm 12 \mathrm{mg}$ (experiment 1) and $2.0 \pm 0.3 \mathrm{mg}$ (experiment 2 ) of each EtOAc fractions.

\section{Isolation of bioactive compounds}

Part of EtOAc fraction from experiment $1(400 \mathrm{mg})$ was subjected to fractionation by Sephadex LH-20 column chromatography $\left(3 \times 50 \mathrm{~cm}\right.$, flow $\left.1.0 \mathrm{~mL} \mathrm{~min}^{-1}\right)$ eluted with $\mathrm{MeOH}$ to afford 83 fractions $(6 \mathrm{~mL}$ each). After analysis by TLC, these fractions were pooled into six groups (I-VI). Group III (122 mg) was purified by reverse phase prep. TLC (RP-18) eluted with $\mathrm{MeOH}: \mathrm{H}_{2} \mathrm{O}(9: 1)$ to afford 3-oxotirucalla-7,24Z-dien-27-oic acid (1, $45 \mathrm{mg})$ and $3 \alpha$-acetoxytirucalla-7,24Z-dien-27-oic acid (3, $4 \mathrm{mg})$. Group IV (95 mg) was subjected to separation on a Sephadex LH-20 column $\left(3 \times 60 \mathrm{~cm}\right.$, flow $\left.0.7 \mathrm{~mL} \mathrm{~min}^{-1}\right)$ eluted with $\mathrm{MeOH}$, to yield 28 fractions $(5 \mathrm{~mL}$ each), which, after monitoring by TLC, were pooled into three groups (IV-1 to IV-3). Group IV-3 (12 mg) was composed by $3 \alpha$-hydroxytirucalla-7,24Z-dien-27-oic acid (2). Group VI $(61 \mathrm{mg})$ was subjected to fractionation on a Sephadex LH-20 column $\left(3 \times 50 \mathrm{~cm}\right.$, flow $\left.1.0 \mathrm{~mL} \mathrm{~min}^{-1}\right)$ eluted with $\mathrm{MeOH}$, yielding 52 fractions (5 mL each), which were pooled into five groups (VI-1 to VI-5) after analysis by TLC. Groups VI-2 (16 mg) and VI-4 $(12 \mathrm{mg})$ were purified by semi-preparative RP-18 HPLC, eluted with $\mathrm{MeOH}: \mathrm{H}_{2} \mathrm{O}\left(8: 2\right.$, flow rates $3.7 \mathrm{~mL} \mathrm{~min}^{-1}$, UV $\left.218 \mathrm{~nm}\right)$ to afford, respectively, gallic acid $(\mathbf{4}, 8 \mathrm{mg})$ and ethyl gallate $(\mathbf{5}, 6 \mathrm{mg})$

\section{Cell lines}

The murine melanoma cell line B16F10 was originally obtained from the Ludwig Institute for Cancer Research (São Paulo, Brazil). The murine melanoma B16F10-Nex2 sub-line is characterized by low immunogenicity and moderate virulence. Human melanoma (A2058), glioblastome (U87), colon carcinoma (HCT), cervical cancer ( $\mathrm{SiHa}$ ), and breast cancer (SKBR-3) cell lines were obtained from the Ludwig Institute for Cancer Research. Human cervical carcinoma (HeLa) was acquired from Dr. Hugo Pequeno Monteiro, UNIFESP. Cells were cultured at $37{ }^{\circ} \mathrm{C}$ in a humidified atmosphere containing $5 \% \mathrm{CO}_{2}$, in RPMI 1640 medium (Invitrogen, Carlsbad, CA) supplemented with $10 \mathrm{mM} \mathrm{N}$-2-hydroxyethylpiperazine- $\mathrm{N}$ 2-ethanesulfonic acid (Hepes) (Sigma, St. Louis, MO), 24 $\mathrm{mM}$ sodium bicarbonate (Sigma), $40 \mathrm{mg} \mathrm{L}^{-1}$ gentamycin (Schering-Plough, São Paulo, Brazil), pH 7.2, and 10\% fetal calf serum (Invitrogen).

In vitro cytotoxic activity

Compounds 1-5 as well as the EtOAc fraction from fruits of S. terebinthifolius (experiment 1) were suspended in DMSO at final concentration of $10 \mathrm{mg} \mathrm{mL}^{-1}$ and then added to complete RPMI medium supplemented with $10 \%$ fetal calf serum. Different concentrations of the compounds 1-5 and EtOAc extract, ranging from 100 to $0 \mu \mathrm{g} \mathrm{mL}^{-1}$, were incubated with $1 \times 10^{4}$ cells in a 96-well plate at $37{ }^{\circ} \mathrm{C}$ and $5 \% \mathrm{CO}_{2}$. After $24 \mathrm{~h}$ of incubation, cell viability was assessed using the Cell Proliferation Kit I (MTT) (Sigma), an MTT-based colorimetric assay as previously described. ${ }^{33,34}$ Readings were made in a plate reader at $570 \mathrm{~nm}$ with a reference of $650 \mathrm{~nm}$. All experiments were performed in triplicates using cisplatin (Sigma) and DMSO 1\% as positive and negative controls, respectively.

\section{Results and Discussion}

Schinus terebinthifolius produces tirucallane triterpenes, flavonoids and gallic acid derivatives, which display important pharmacological activities. ${ }^{4-12}$ Aiming the extraction of cytotoxic derivatives from fruits of this species, in this work was employed an alternative extraction method based in the use of ionic liquid extraction assisted by microwave. Using this approach, extracting plant material with $\mathrm{BMImBr}$ aqueous solution at $3 \mathrm{~mol} \mathrm{~L}^{-1}$ (experiment 1), followed by partition using EtOAc, were obtained $460 \pm 12 \mathrm{mg}$ (yield 23\%) of EtOAc fraction. The same procedure was conducted using pure distillated $\mathrm{H}_{2} \mathrm{O}$ (experiment 2) to afford $2.0 \pm 0.3 \mathrm{mg}$ (yield $0.1 \%$ ) of EtOAc fraction, at the same MAE conditions. Each experiment was conducted in triplicate. This result showed that the use this ionic liquid affected the extraction of S. terebinthifolius metabolites, which could be explained by the dissolution of $\mathrm{BMImBr}$ in $\mathrm{H}_{2} \mathrm{O}$ to form ionic liquid clusters due to its strong interactions, such as ionic interaction and hydrogen bonding. Therefore, it is possible to assume that these clusters could accommodate the metabolites and establish interactions with the ions, optimizing the extraction process. In addition, based in the fact that ionic liquids are microwave absorber, this 
heating method showed to be more efficient than that using exclusively $\mathrm{H}_{2} \mathrm{O}$. Moreover, the efficiency of ionic liquids containing bromide anion in dissolving organic compounds have been indicated by the previously reported results. ${ }^{18,30,35}$ Thus, using reduced amount of $\mathrm{BMImBr}$ in $\mathrm{H}_{2} \mathrm{O}$ was observed an efficacy in extraction of metabolites from fruits of $S$. terebinthifolius.

After this extraction procedure, EtOAc fraction obtained from experiment 1 was purified by chromatographic techniques and the structures of isolated compounds (Figure 2) were confirmed as 3-oxotirucalla-7,24Z-dien-27oic acid (Z-masticadienoic acid, 1), 3 $\alpha$-hydroxytirucalla7,24Z-dien-27-oic acid (Z-schinol, 2), 3 $\alpha$-acetoxytirucalla7,24Z-dien-27-oic acid (3), gallic acid (4), and ethyl gallate (5) by NMR spectral data analysis and comparison with

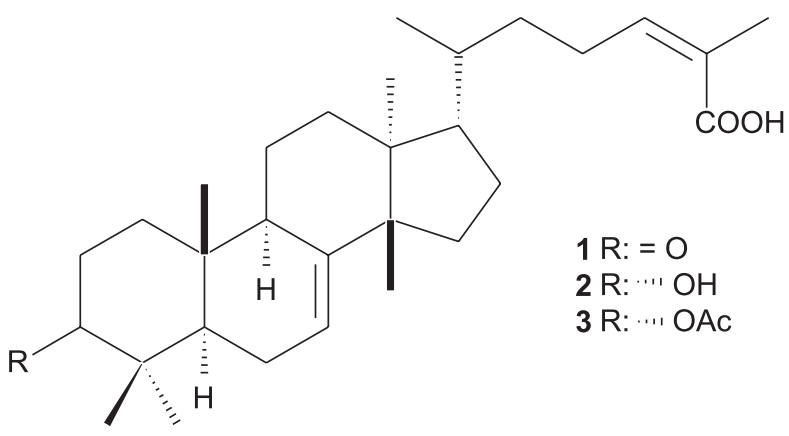<smiles>[R]OC(=O)c1cc(O)c(O)c(O)c1</smiles>

Figure 2. Structures of compounds $\mathbf{1 - 5}$ isolated from fruits S. terebinthifolius by MAE and BMImBr. those described in the literature. ${ }^{10}$ This is the first occurrence of $\mathbf{3}$ as natural product.

Aiming the discovery of new antitumoral compounds from Brazilian flora, the cytotoxic activity of EtOAc fraction obtained after extraction using ionic liquids from fruits of S. terebinthifolius (experiment 1) and compounds 1-5 were evaluated against B16F10-Nex2, A2058, HeLa, SiHa, HCT, SKBR-3, and U87 tumor cell lines (Table 1).

According to the colorimetric assay of MTT and light microscopy, all isolated compounds killed $100 \%$ of cytotoxic cells at the highest tested concentration, resulting in $\mathrm{IC}_{50}$ values in the range of $10.9 \pm 1.3$ to $94.0 \pm 1.5 \mu \mathrm{g} \mathrm{mL} \mathrm{L}^{-1}$. Comparison of the $\mathrm{IC}_{50}$ values to related tirucallane derivatives 1-3 demonstrated that these three derivatives displayed different cytotoxic potentials, suggesting an important effect caused by the substituent in C-3. Compound $\mathbf{1}$, which displayed a carbonyl group, showed higher $\mathrm{IC}_{50}$ values, ranging from $25.0 \pm 1.3$ (U87) to $53.0 \pm 1.2 \mu \mathrm{gLL}^{-1}$ (HCT), in comparison to the other tirucallane derivatives $\mathbf{2}$ and $\mathbf{3}$. As could be seen in Table 1, compound $\mathbf{2}$, which displayed a hydroxyl group at C-3, was more active than 1, except to U87, A2058 and B16F10 Nex 2 cell lines, suggesting that the reduction of carbonyl group at C-3 could cause an important effect in the cytotoxicity. Otherwise, the $\mathrm{IC}_{50}$ values determined to compound 3 indicated an expressive increase in the cytotoxicity since $\mathrm{IC}_{50}$ values were lower than $20 \mu \mathrm{g} \mathrm{mL}^{-1}$ to all tested cell lines, indicating that the presence of acetoxyl group at C-3 play an important role in the cytotoxic effects of tirucallane derivatives. Additionally, it is important to mention that compound $\mathbf{3}$ displayed higher potential than positive control cisplatin in five cell lines, suggesting that this compound could be used as scaffold to the development of new compounds with promising cytotoxic activity based in natural products.

Compounds $\mathbf{4}$ and $\mathbf{5}$ have previously been described as cytotoxic against cell lines HeLa and A2058, ${ }^{12}$ although in this study have been tested against other cell lines.

Table 1. Cytotoxic activity of crude EtOAc fraction (experiment 1) and compounds 1-5 isolated from fruits of S. terebinthifolius after extraction using $\mathrm{MAE} / \mathrm{BMImBr}$ as well as positive control cisplatin against different tumor cell lines

\begin{tabular}{lccccccc}
\hline \multirow{2}{*}{ Tumor cell line } & \multicolumn{7}{c}{$\mathrm{IC}_{50} /\left(\mu \mathrm{g} \mathrm{mL}^{-1}\right)$} \\
\cline { 2 - 7 } & EtOAc phase & $\mathbf{1}$ & $\mathbf{2}$ & $\mathbf{3}$ & $\mathbf{4}$ & $\mathbf{5}$ & Cisplatin \\
\hline B16F10-Nex 2 & $78.3 \pm 0.4$ & $33.1 \pm 0.3$ & $36.7 \pm 1.1$ & $16.3 \pm 0.9$ & $15.2 \pm 1.6$ & $34.7 \pm 1.7$ & $53.1 \pm 4.2$ \\
A2058 & $>200$ & $37.7 \pm 0.9$ & $50.2 \pm 1.4$ & $12.2 \pm 0.3$ & $46.0 \pm 1.4$ & $94.0 \pm 1.5$ & $43.1 \pm 3.6$ \\
HeLa & $78.5 \pm 3.6$ & $52.4 \pm 0.3$ & $34.6 \pm 2.1$ & $14.0 \pm 1.1$ & $13.3 \pm 0.8$ & $54.8 \pm 1.3$ & $20.0 \pm 1.3$ \\
SiHa & $71.3 \pm 3.2$ & $51.3 \pm 1.0$ & $32.4 \pm 2.8$ & $13.8 \pm 0.9$ & $38.2 \pm 2.1$ & $49.9 \pm 1.6$ & $\mathrm{nd}$ \\
HCT & $68.3 \pm 7.4$ & $53.0 \pm 1.2$ & $37.4 \pm 1.9$ & $10.9 \pm 1.3$ & $12.3 \pm 0.5$ & $43.6 \pm 2.9$ & $67.5 \pm 2.1$ \\
SKBR-3 & $>200$ & $>200$ & $40.2 \pm 2.6$ & $15.6 \pm 0.7$ & $23.9 \pm 2.3$ & $66.3 \pm 2.5$ & $\mathrm{nd}$ \\
U87 & $98.3 \pm 5.3$ & $25.0 \pm 1.3$ & $38.1 \pm 1.1$ & $17.3 \pm 1.4$ & $21.6 \pm 0.7$ & $54.7 \pm 3.2$ & $45.2 \pm 5.9$ \\
\hline
\end{tabular}

nd: not determined. 
Thus, these compounds showed cytotoxic activity to all tested cell lines with $\mathrm{IC}_{50}$ values ranging from $12.3 \pm 0.5$

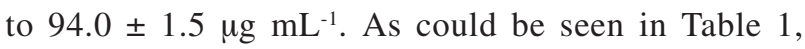
compound 4 was the more active derivative, especially to B16F10Nex2 $\left(15.2 \pm 1.6 \mu \mathrm{g} \mathrm{mL}^{-1}\right), \mathrm{HeLa}(13.3 \pm 0.8 \mu \mathrm{g}$ $\left.\mathrm{mL}^{-1}\right), \mathrm{HCT}\left(12.3 \pm 0.5 \mu \mathrm{g} \mathrm{mL}^{-1}\right), \mathrm{SKBR}-3(23.9 \pm 2.3 \mu \mathrm{g}$ $\left.\mathrm{mL}^{-1}\right)$ and U87 $\left(21.6 \pm 0.7 \mu \mathrm{g} \mathrm{mL}^{-1}\right)$ cells. Similarly to the previous results to antiparasitic activity, ${ }^{10}$ the obtained data indicated that the presence of free carboxyl group in the gallic acid is crucial to the cytotoxic potential. However, the use of galloyl derivatives as bioactives must be carefully employed since these compounds could be considered as PAINS (Pan Assay Interference Compounds) since they displayed a catechol unit which can interfere in bioassays via different mechanisms. ${ }^{36}$

Despite the isolated compounds $\mathbf{1 , 2 , 4}$ and $\mathbf{5}$ have already been described for the leaves of $S$. terebinthifolius, ${ }^{10-12}$ this study demonstrate, at first time, that it is possible to extract these bioactive compounds using a more sustainably method based in the microwave assisted by ionic liquid. Additionally, this work report the cytotoxic effects of compounds 1-5, highlighting the activity observed for compound 3 which displayed lower $\mathrm{IC}_{50}$ values of those observed to positive control (cisplatin) to five cell lines.

\section{Conclusion}

Ionic liquids have attracted considerable attention as solvents in the extraction and separation of bioactive compounds from plants owing to their excellent properties. In this work, the application of microwave-assisted extraction (MAE) using an ionic liquid aqueous solution (1-butyl-3-methylimidazolium bromide, BMImBr) showed to be an efficient procedure to the extraction of cytotoxic metabolites from fruits of $S$. terebinthifolius. After partition with EtOAc, the extraction yield was approximately $23 \%$ in one single step and short time (10 minutes, experiment 1 ). Comparatively, the use of pure $\mathrm{H}_{2} \mathrm{O}$ as solvent extractor (experiment 2 ) afforded a yield of $0.1 \%$, showing that the presence of $\mathrm{BMImBr}$ dissolved in $\mathrm{H}_{2} \mathrm{O}$ is fundamental for the success of the extraction. The ionic liquid changes the dissipation factor of solution and the transfer of energy from microwaves to sample, which affected extraction efficiency. The proposed technique was green, simple and rapid. It is strongly believed that an ionic liquid aqueous solution as solvents in the MAE of useful substances in natural sources is a new and interesting approach. Additionally, the EtOAc fraction (experiment 1) displayed cytotoxic activity and was subjected to several chromatographic steps to afford five bioactive compounds, including three tirucallane triterpenoids (1-3) and two gallate derivatives (4-5). Among the isolated compounds, $3 \alpha$-acetoxytirucalla-7,24Z-dien27-oic acid (3) displayed higher cytotoxic potential against five cell lines, suggesting that this triterpene could be considered as a lead anti-leukemic agent.

\section{Supplementary Information}

Supplementary material is available free of charge at http://jbcs.sbq.org.br as PDF file.

\section{Acknowledgments}

This work was supported by grants from FAPESP (BIOTA 2011/51739-6 and 2015/11936-2). T. R. M. obtained a fellowship from CAPES; A. P. C., F. F. C., P. S. and J. H. G. L. received a scientific research award from CNPq.

\section{References}

1. Corrêa, M. P.; Dicionário de Plantas Úteis do Brasil e das Exóticas Cultivadas, vol. 1; Imprensa Nacional: Rio de Janeiro, 1984.

2. Lorenzi, H.; Matos, F. J. A.; Plantas Medicinais do Brasil: Nativas e Exóticas; Instituto Plantarum: Nova Odessa, 2002.

3. Schmourlo, G.; Mendonça-Filho, R. R.; Alviano, C. S.; Costa, S. S.; J. Ethnopharmacol. 2005, 96, 563.

4. Jain, M. K.; Yu, B. Z.; Rogers, J. M.; Smith, A. E.; Boger, E. T. A.; Ostrander, R. L.; Rheingold, A. L.; Phytochemistry 1995, 39, 537.

5. Moneam, N. M. A.; Ghoneim, T.; J. Chromatogr. A 1986, 361, 391.

6. Lloyd, H. A.; Jaouni, T. M.; Evans, S. L.; Morton, J. F.; Phytochemistry 1977, 16, 1301.

7. Campello, J. P.; Marsaioli, A. J.; Phytochemistry 1975, 14, 2300.

8. Campello, J. P.; Marsaioli, A. J.; Phytochemistry 1974, 13, 659.

9. Johann, S.; Sá, N. P.; Lima, L. A. R. S.; Cisalpino, P. S.; Cota, B. B.; Alves, T. M. A.; Siqueira, E. P.; Zani, C. L.; Ann. Clin. Microbiol. Antimicrob. 2010, 9, 30.

10. Morais, T. R.; Costa-Silva, T.; Tempone, A. G.; Borborema, S. E. T.; Scotti, M. T.; Souza, R. M. F.; Araujo, A.; Oliveira, A.; Morais, S.; Sartorelli, P.; Lago, J. H. G.; Molecules 2014, 19, 5761.

11. Ceruks, M.; Romoff, P.; Favero, O. A.; Lago, J. H. G.; Quim. Nova 2007, 30, 597.

12. Santana, J. S.; Sartorelli, P.; Lago, J. H. G.; Matsuo, A. L.; Quim. Nova 2012, 35, 2245.

13. Wasserscheid, P.; Welton, T.; Ionic Liquids in Synthesis, $1^{\text {st }}$ ed.; Wiley-VCH: New York, 2003.

14. Swatloski, R. P.; Spear, S. K.; Holbrey, J. D.; Rogers, R. D.; J. Am. Chem. Soc. 2002, 124, 4974. 
15. Rogers, R. D.; Seddon, K. R.; Ionic Liquids: Industrial Applications for Green Chemistry, $1^{\text {st }}$ ed.; American Chemical Society: Nova York, 2002.

16. Bridges, N. J.; Rogers R. D.; Visser A. N.; Ionic Liquid: Science And Applications, $1^{\text {st }}$ ed.; Oxford University Press: New York, 2013.

17. Daí, Y.; Spronsen, J. V.; Witkamp, G.-J.; Veepoorte, R.; Choi, Y. H.; J. Nat. Prod. 2013, 76, 2162.

18. Du, F. Y.; Xiao, X. H.; Li, G. K.; J. Chromatogr. A 2007, 1140, 56.

19. Du, F. Y.; Xiao, X. H.; Luo, X. J.; Li, G. K.; Talanta 2009, 78, 1177.

20. Zeng, H.; Wang, Y.; Kong, J.; Nie, C.; Yuan, Y.; Talanta 2010 , $83,582$.

21. Zhang, L.; Wang, X.; J. Sep. Sci. 2010, 33, 2035.

22. Cao, X.; Ye, X.; Lu, Y.; Yu, Y.; Mo, W.; Anal. Chim. Acta 2009, $640,47$.

23. Lu, Y.; Ma, W.; Hu, R.; Dai, X.; Pan, Y.; J. Chromatogr. A 2008 , $1208,42$.

24. Zhang, L. J.; Geng, Y. L.; Duan, W. J.; Wang, D. J.; Fu, M. R.; Wang, X.; J. Sep. Sci. 2009, 32, 3550.

25. Ma, W.; Lu, Y.; Hu, R.; Chen, J.; Zhang, Z.; Pan, Y.; Talanta 2010, 80, 1292.

26. Francisco, M.; Lago, S.; Soto, A.; Arce, A.; Fluid Phase Equilib. 2010, 296, 149.
27. Lapkin, A. A.; Plucinski, P. K.; Cutler, M.; J. Nat. Prod. 2006, 69, 1653.

28. Fan, J.; Fan, Y.; Pei, Y.; Wu, K.; Wang, J.; Fan, M.; Sep. Purif. Technol. 2008, 61, 324.

29. Zhai, Y.; Sun, S.; Wang, Z.; Cheng, J.; Sun, Y.; Wang, L.; Zhang, Y.; Zhang, H.; Yu, A.; J. Sep. Sci. 2009, 32, 3544.

30. Swatloski, R. P.; Spear, S. K.; Holbrey, J. D.; Rogers, R. D.; J. Am. Chem. Soc. 2002, 124, 4974.

31. Dallinger, D.; Kappe, C. O.; Chem. Rev. 2007, 107, 2563.

32. Huddleston, J. G.; Visser, A. E.; Reichert, W. M.; Willauer, H. D.; Broker, G. A.; Rogers, R. D.; Green Chem. 2001, 3, 156.

33. Matsuo, A. L.; Figueiredo, C. R.; Arruda, D. C.; Pereira, F. V.; Scutti, J. A. B.; Massaoka, M. H.; Travassos, L. R.; Sartorelli, P.; Lago, J. H. G.; Biochem. Biophys. Res. Comm. 2011, 411, 449.

34. Mosmann, T.; J. Immunol. Methods 1983, 65, 55.

35. Xie, H.; Li, S.; Zhang, S.; Green Chem. 2005, 7, 606.

36. Baell, J. B.; J. Nat. Prod. 2016, 79, 616.

Submitted: May 9, 2016 Published online: July 19, 2016

FAPESP has sponsored the publication of this article. 